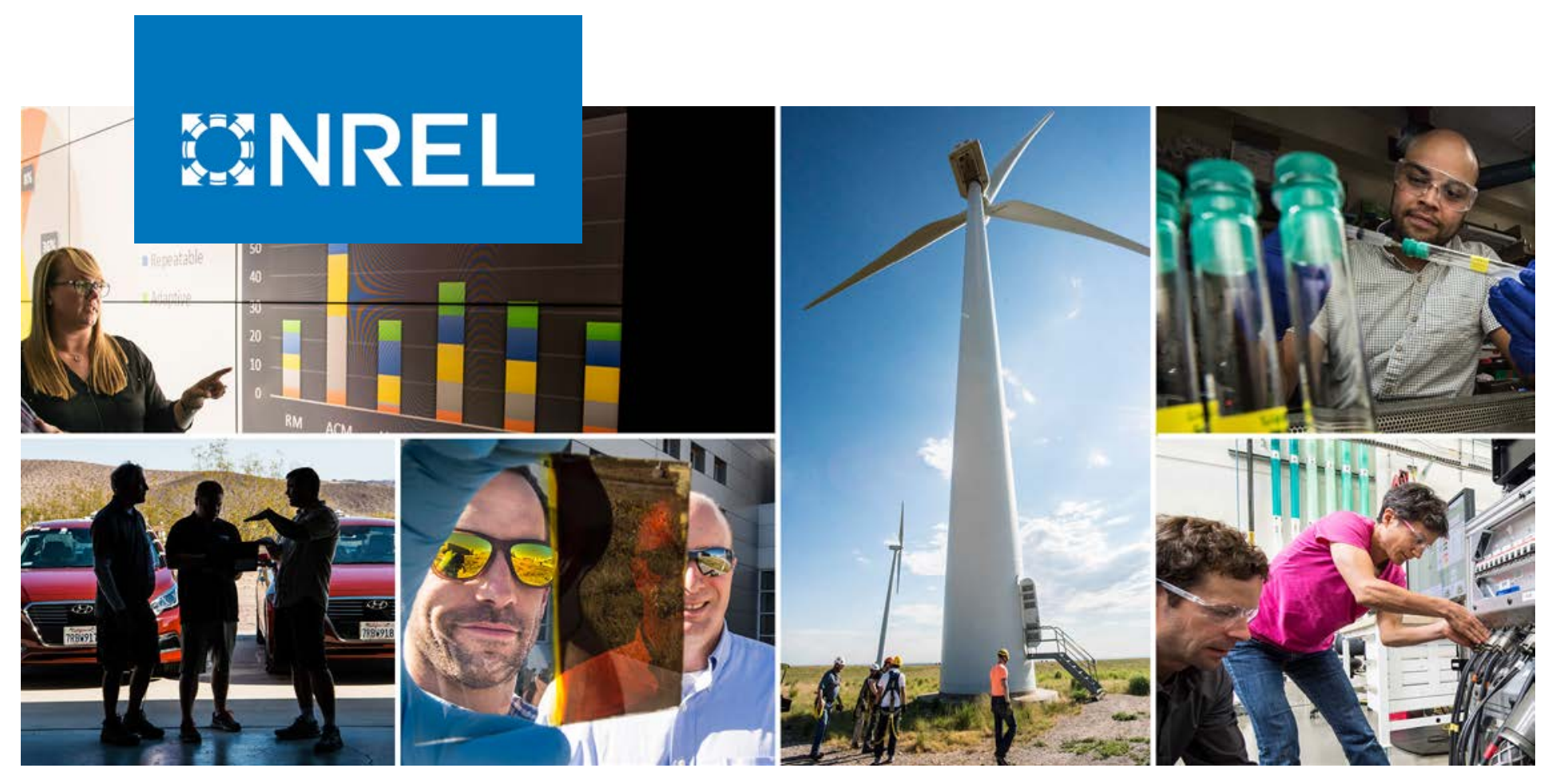

\title{
Fuel Cell Electric Vehicle Durability and Fuel Cell Performance
}

Jennifer Kurtz, Sam Sprik, Genevieve Saur, and Shaun Onorato

National Renewable Energy Laboratory

NREL is a national laboratory of the U.S. Department of Energy

Office of Energy Efficiency \& Renewable Energy

Operated by the Alliance for Sustainable Energy, LLC

This report is available at no cost from the National Renewable Energy Laboratory (NREL) at www.nrel.gov/publications.

\section{Technical Report}

NREL/TP-5400-73011

March 2019 


\title{
GNREL
}

\section{Fuel Cell Electric Vehicle Durability and Fuel Cell Performance}

\author{
Jennifer Kurtz, Sam Sprik, Genevieve Saur, \\ and Shaun Onorato
}

National Renewable Energy Laboratory

\section{Suggested Citation}

Kurtz, Jennifer, Sam Sprik, Genevieve Saur, and Shaun Onorato. 2019. Fuel Cell Electric Vehicle Durability and Fuel Cell Performance. Golden, CO: National Renewable Energy Laboratory. NREL/TP-5400-73011. https://www.nrel.gov/docs/fy19osti/73011.pdf.

NREL is a national laboratory of the U.S. Department of Energy Office of Energy Efficiency \& Renewable Energy Operated by the Alliance for Sustainable Energy, LLC

This report is available at no cost from the National Renewable Energy Laboratory (NREL) at www.nrel.gov/publications.

Contract No. DE-AC36-08GO28308
Technical Report NREL/TP-5400-73011 March 2019

National Renewable Energy Laboratory 15013 Denver West Parkway Golden, CO 80401 303-275-3000 • www.nrel.gov 


\section{NOTICE}

This work was authored by the National Renewable Energy Laboratory, operated by Alliance for Sustainable Energy, LLC, for the U.S. Department of Energy (DOE) under Contract No. DE-AC36-08GO28308. Funding provided by U.S. Department of Energy Office of Energy Efficiency and Renewable Energy Fuel Cell Technologies Office. The views expressed herein do not necessarily represent the views of the DOE or the U.S. Government.

This report is available at no cost from the National Renewable Energy Laboratory (NREL) at www.nrel.gov/publications.

U.S. Department of Energy (DOE) reports produced after 1991 and a growing number of pre-1991 documents are available free via www.OSTI.gov.

Cover Photos by Dennis Schroeder: (clockwise, left to right) NREL 51934, NREL 45897, NREL 42160, NREL 45891, NREL 48097, NREL 46526.

NREL prints on paper that contains recycled content. 


\section{Acknowledgements}

This work was supported by the U.S. Department of Energy Fuel Cell Technologies Office in the Office of Energy Efficiency and Renewable Energy. 


\section{List of Acronyms}

CDP

DOE

EPA

FCEV

FCTO

NHTS

LD

MYRD\&D

NFCTEC

NREL

OEM composite data product

U.S. Department of Energy

U.S. Environmental Protection Agency

fuel cell electric vehicle

Fuel Cell Technologies Office

National Household Travel Survey

Learning Demonstration

Multi-Year Research, Development, and Demonstration Plan

National Fuel Cell Technology Evaluation Center

National Renewable Energy Laboratory

original equipment manufacturer 


\section{Summary}

The objectives of this project are to validate hydrogen fuel cell electric vehicles (FCEVs) in realworld settings and to identify the current status and evolution of the technology. The analysis objectively assesses progress toward targets and market needs defined by the U.S. Department of Energy and stakeholders, provides feedback for early-stage hydrogen research and development, and publishes results for key stakeholder use and investment decisions. Fiscal year 2018 objectives focus on analysis and reporting of FCEV driving range, fuel economy, drive and fill behaviors, durability, fill performance, and fuel cell performance. This report specifically addresses the topics of fuel cell stack durability and fuel cell performance.

Keywords: fuel cell, hydrogen, FCEV, driving range, fuel economy, fill performance, drive and fill behaviors, NFCTEC, National Fuel Cell Technology Evaluation Center, National Renewable Energy Laboratory, NREL 


\section{Table of Contents}

Introduction and Background......................................................................................................... 1

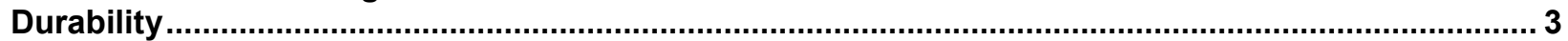

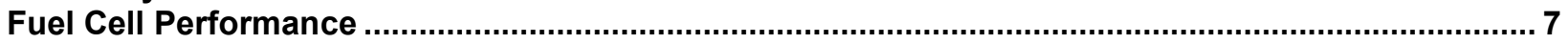

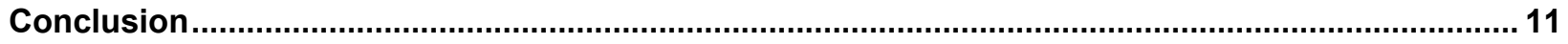

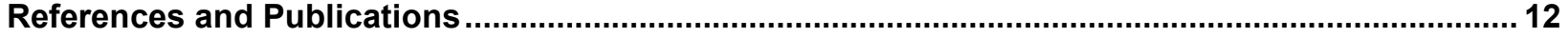




\section{Introduction and Background}

The National Renewable Energy Laboratory's (NREL's) objective in this project is to support the U.S. Department of Energy (DOE) in the technical evaluation of hydrogen fuel cell electric vehicles (FCEVs) under real-world conditions. This is accomplished through evaluating and analyzing data from the FCEVs to identify the current status of the technology, compare it to DOE program targets, and assist in evaluating progress between multiple generations of FCEV technology. DOE funds projects for the collection and delivery of data to the National Fuel Cell Technology Evaluation Center (NFCTEC) at NREL for analysis, aggregation, and reporting. The effort has been ongoing since the U.S. Department of Energy Fuel Cell Technologies Office Learning Demonstration project began in 2005.

The project partners include six original equipment manufacturers (OEMs): General Motors, Honda, Hyundai, Mercedes-Benz, Nissan, and Toyota. Three OEMs (Nissan, Toyota, and Honda) submit data under one DOE project awarded to Electricore Inc. Each project partner had more than one vehicle included in this evaluation project, referred to as a FCEV fleet, for a total of six fleets. These vehicles are a mixture of pre-commercial and commercial vehicles, operated within fleets and by individual drivers, with model years from 2005 to 2012. The Toyota Mirai and Hyundai Nexo were not included in the analysis due to lack of data contribution and/or model year not being available during the evaluation timeline. The OEMs supply on-road vehicle data to NREL for evaluation in the following categories: fuel cell stack durability, deployment (e.g., number of vehicles included), system specifications, range, fuel economy, efficiency, fill performance, reliability, drive and fill behaviors, power and energy management, fuel cell transients (e.g., frequency of rapid increases or decreases in fuel cell power), benchmarking against technical targets and typical gasoline vehicle operation, maintenance, on-board storage, and safety. The on-road vehicle data are supplied to NFCTEC at least every 3 months. More details about the project and background information can be found in the overview report (Kurtz et al. 2018).

Evaluation metrics, specifically in the categories of fuel cell durability, efficiency, specifications, and hydrogen storage, are derived from the DOE Fuel Cell Technologies Office Multi-Year Research, Development, and Demonstration Plan ${ }^{1}$ (MYRD\&D). MYRD\&D metrics are also used in some of the composite data products (CDPs) contained in this report to benchmark progress against the target. This report specifically addresses the topics of fuel cell stack durability and fuel cell performance.

Data from the current technology validation project are incorporated into the results of previous vehicle technology validation projects. ${ }^{2}$ The FCEV Learning Demonstration - also referred to as the Controlled Hydrogen Fleet and Infrastructure Demonstration and Validation Project - has been ongoing since 2005 and is currently in the fourth phase. The current FCEV technology advancements and technology generations are varied between the OEMs due to their individual

\footnotetext{
${ }^{1}$ DOE Fuel Cell Technologies Office Multi-Year Research, Development, and Demonstration Plan, https:/www.energy.gov/eere/fuelcells/downloads/fuel-cell-technologies-office-multi-year-research-developmentand-22

${ }^{2}$ National Fuel Cell Electric Vehicle Learning Demonstration Final Report, https://www.nrel.gov/hydrogen/learning-demo.html
} 
development and production schedules. These different phases of the Learning Demonstration project can show the trend of newer generations of FCEVs but don't necessarily correspond to the newest technology for a given year. 


\section{Durability}

On-road FCEV durability has been studied by NREL for more than 10 years with multiple vehicle manufacturers and over several vehicle/fuel cell generations. Fuel cell durability results were initially published in 2006 (after one year of data collection under the first generation of the Learning Demonstration project) and then reported on for each analysis phase of the project. FCEVs in a fleet and a reporting period are of the same generation and design.

FCEVs have made steady progress toward the DOE MYRD\&D 2020 target of 5,000 hours with less than $10 \%$ loss of performance (with an ultimate target of 8,000 hours at $10 \%$ loss of performance). This performance loss is characterized by the point at which $10 \%$ voltage degradation occurs when a new fuel cell stack enters service. Fuel cell power systems must be equivalently durable and reliable to compete with internal combustion engines; therefore, a target of 5,000 hours was chosen as it is equivalent to approximately 150,000 miles of conventional vehicle driving range. It is important to note that the DOE voltage degradation targets are not necessarily representative of what vehicle OEMs or industry consider end of life performance (or indicative of catastrophic fuel cell stack failure).

As of spring 2018, the Learning Demonstration projects have analyzed the data from more than 230 vehicles from the six OEMs. These vehicles have generated operational data for more than 7 million miles traveled and more than 83,000 hours of fuel cell stack operation time. As a note, most vehicles included in this study were early generation demonstration and pre-production models dating back to 2006. Data from the latest generation of commercially available FCEVs were not included in the analysis due to restrictions in contract or a lack of a contributing data partner. Figure 1 shows fuel cell stack operation hours from the start of the evaluation to present. The figure includes both in service vehicles and those that have been retired during the evaluation. Vehicles were retired due to performance loss, end of fuel cell life, end of vehicle test, or other catastrophic failure unrelated to the fuel cell system. As of spring 2018, more than $22 \%$ of the fuel cell stacks tested had more than 2,000 hours of operation with a maximum operation time of 5,648 hours (which exceeds the DOE 2020 operation hour target of 5,000 hours). Most of the in-service vehicles fall within the operation range of 1,500 to 2,000 hours as observed in Figure 1. It is worth noting that in-service vehicles may have low operation hours due to length of service, not operational problems.

Two parameters used in this evaluation to track and validate system durability are actual operation hours and projected operation time to $10 \%$ voltage degradation. The voltage durability trend from four unique reporting periods is shown in Figure 2, which compares fuel cell durability in operating hours to $10 \%$ voltage degradation across the various evaluation years. The operation time to $10 \%$ voltage degradation for each stack in a fleet is used to determine the fleet average voltage degradation value. This allows a comparison across fleets comprising different numbers of vehicles. Since the onset of the Learning Demonstration project in 2006 through 2016, the average fleet durability has increased $162 \%$ from 1,000 hours to 2,000 hours and the max fleet average durability has increased 129\% from 2,000 hours to 4,000 hours (see Figure 2). As fuel cell durability and the underlying fundamental technology improve, extrapolating the current trend shows that the maximum fleet durability should meet the DOE MYRD\&D 2020 durability target in the next $2-4$ years. However, the average fleet durability is currently not on 
track to meet the MYRD\&D 2020 durability target. Durability is expected to increase as older model vehicles retire and newer models are added to the fleet data.

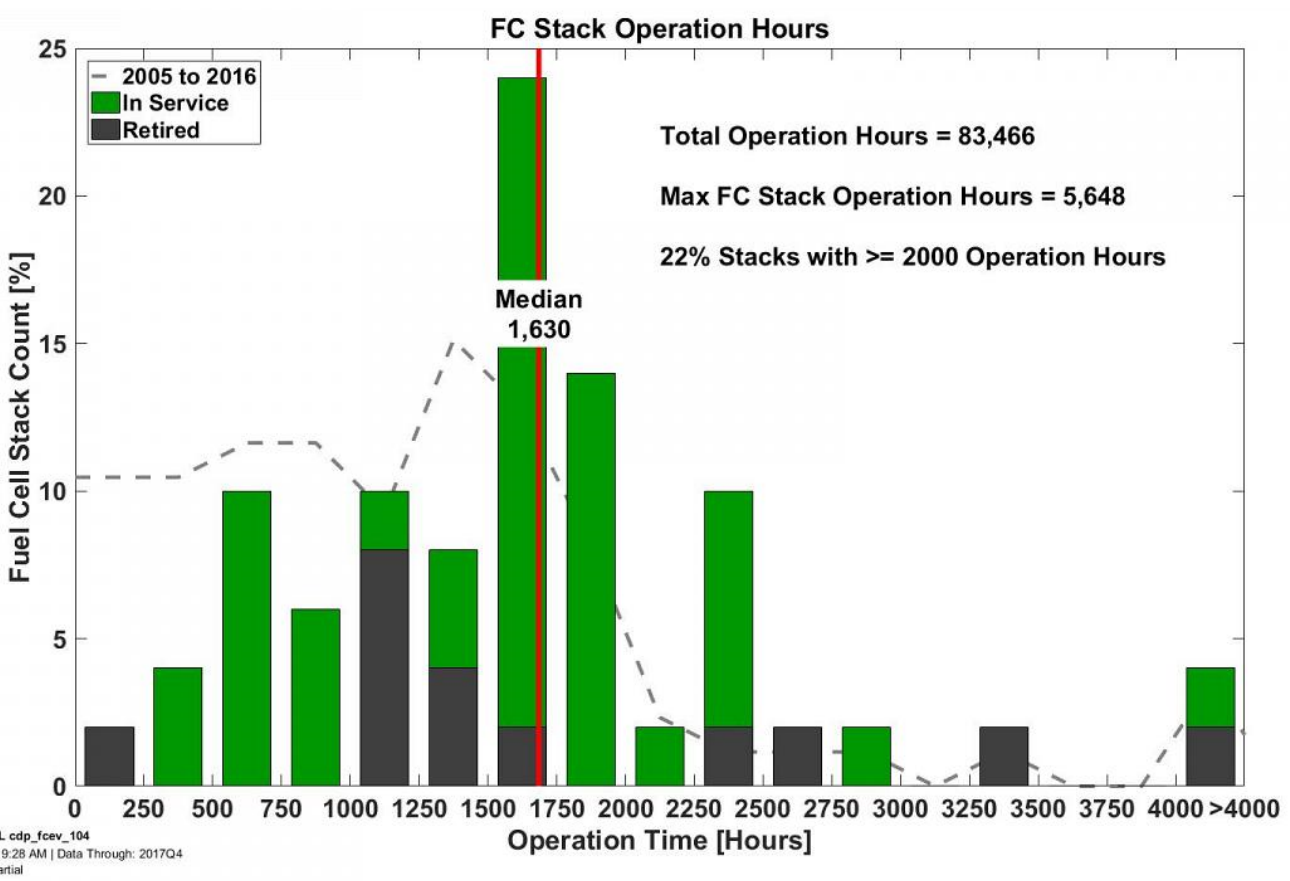

Figure 1. Fuel cell stack operation hours (CDP-FCEV-104)

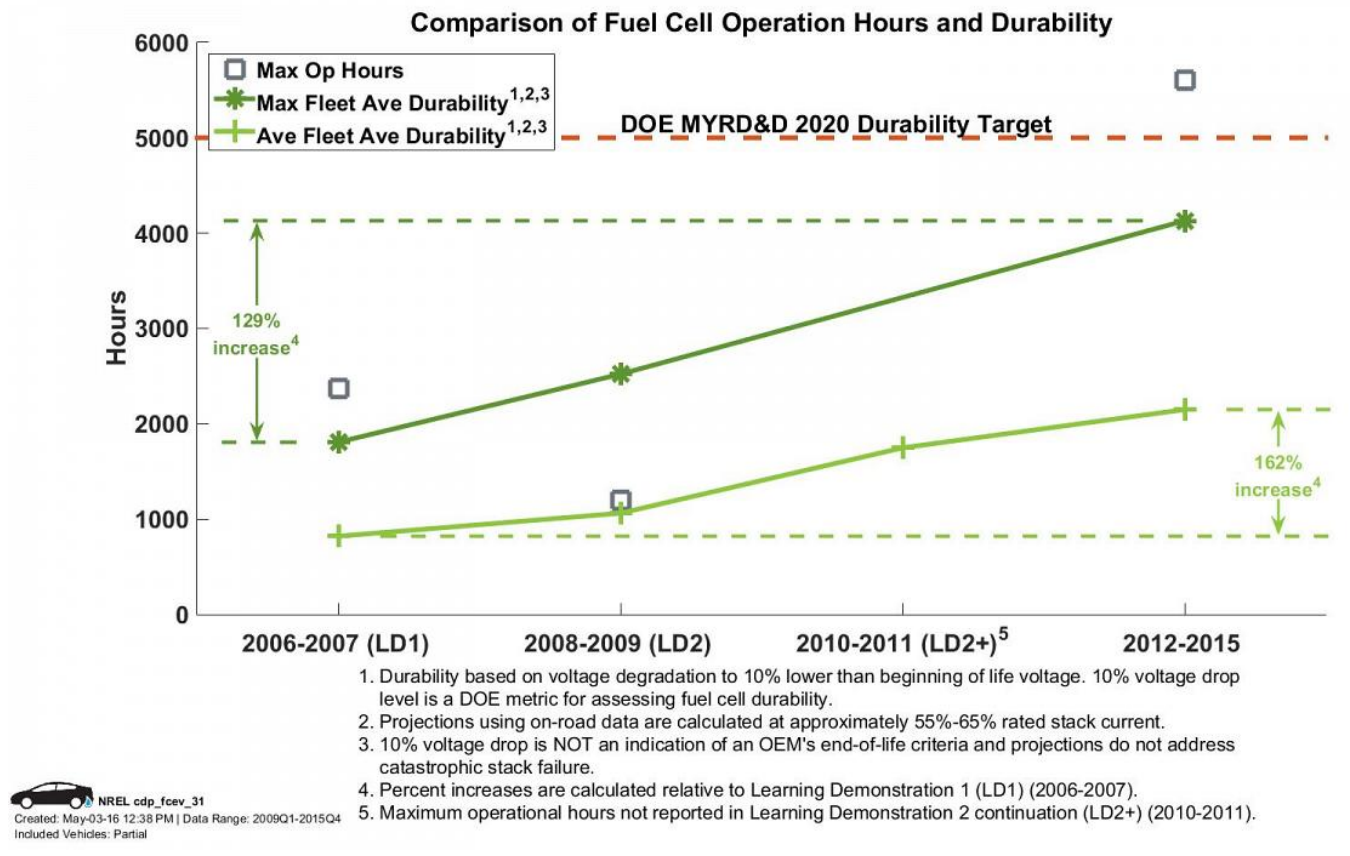

Figure 2. Fuel cell operation hours and voltage degradation trend (CDP-FCEV-31) 
Figure 3 shows the relationship between average fleet fuel cell stack voltage durability as a function of voltage drop levels. This CDP was developed to understand the progressions at higher levels of voltage degradation above the $10 \%$ voltage degradation metric and towards stack end of life. A fairly linear relationship indicates that fleet average hours of fuel cell operation may be a good predictor of overall fleet voltage drop. The data shows for the average fleet projection that $10 \%$ degradation occurs at approximately 2,000 hours and approximately $30 \%$ degradation occurs at 5,000 hours. OEMs will need to significantly improve performance to meet the DOE MYRD\&D 5,000-hour target. DOE metrics may not be reflective of what OEMs consider acceptable end of life performance or related to catastrophic stack failure.

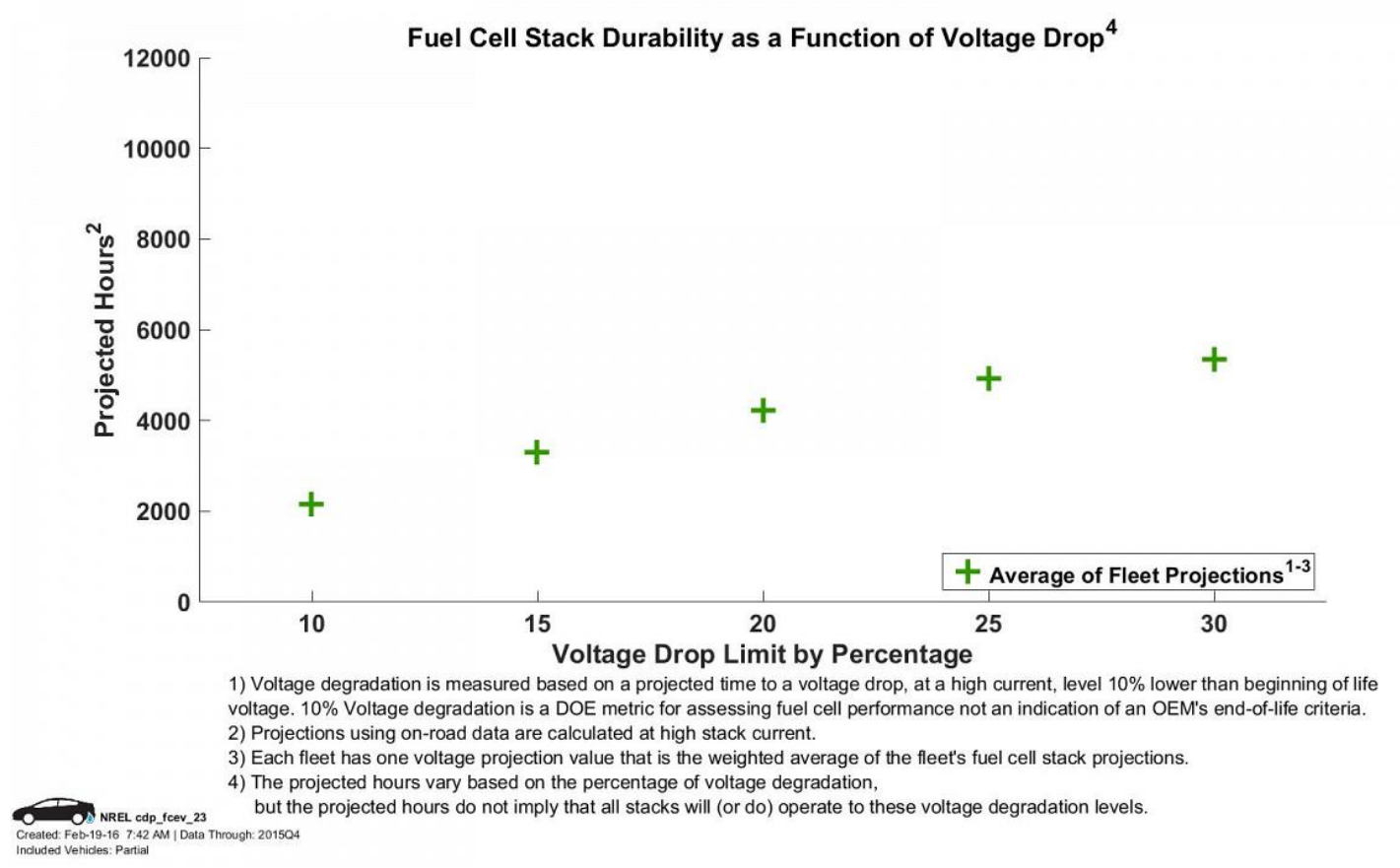

Figure 3. Fuel cell stack voltage durability as a function of voltage drop levels (CDP-FCEV-23)

Figure 4 quantifies voltage degradation predictions made by NREL and breaks them down into percentages of fuel cell power plants with greater and less than $10 \%$ voltage degradation. The analysis supports the findings in previous figures that show a large percentage of fuel cell stacks experienced greater than $10 \%$ voltage degradation past the 1,000-hour operation time. In contrast, $63.6 \%$ of all stacks submitting data have not operated past the $10 \%$ voltage degradation mark at or under 2,500 hours of operation.

Due to durability results indicating fleets are operating short of the DOE targets, an analysis was completed to take a closer look at the effects of voltage degradation on maximum power below 2,000 hours of operation time. In Figure 5, the error bar chart shows the gradual decline of the average fleet power over time. The 25 th and 75 th percentiles stay relatively constant, indicating the data sets do not widely vary. The median power difference was observed to be $-9.73 \%$ at 1,900 hours or roughly $10 \%$ degradation as observed in other CDPs. 
For further analysis into fuel cell degradation mechanisms, reference the Chemical Reviews scientific journal article Scientific Aspects of Polymer Electrolyte Fuel Cell Durability and Degradation (Borup et al. 2007).

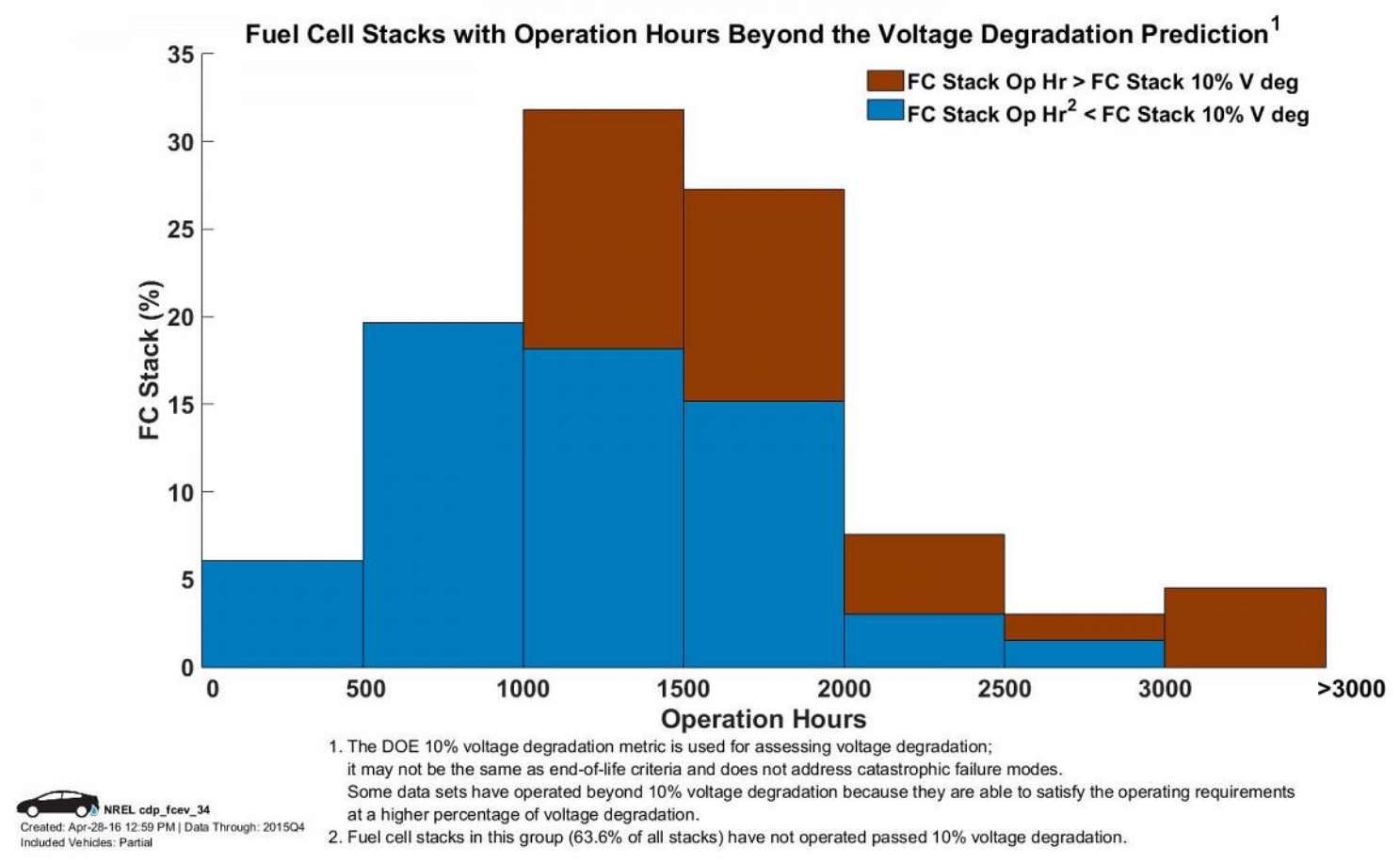

Figure 4. Fuel cell operation hours beyond $10 \%$ voltage degradation (CDP-FCEV-34)

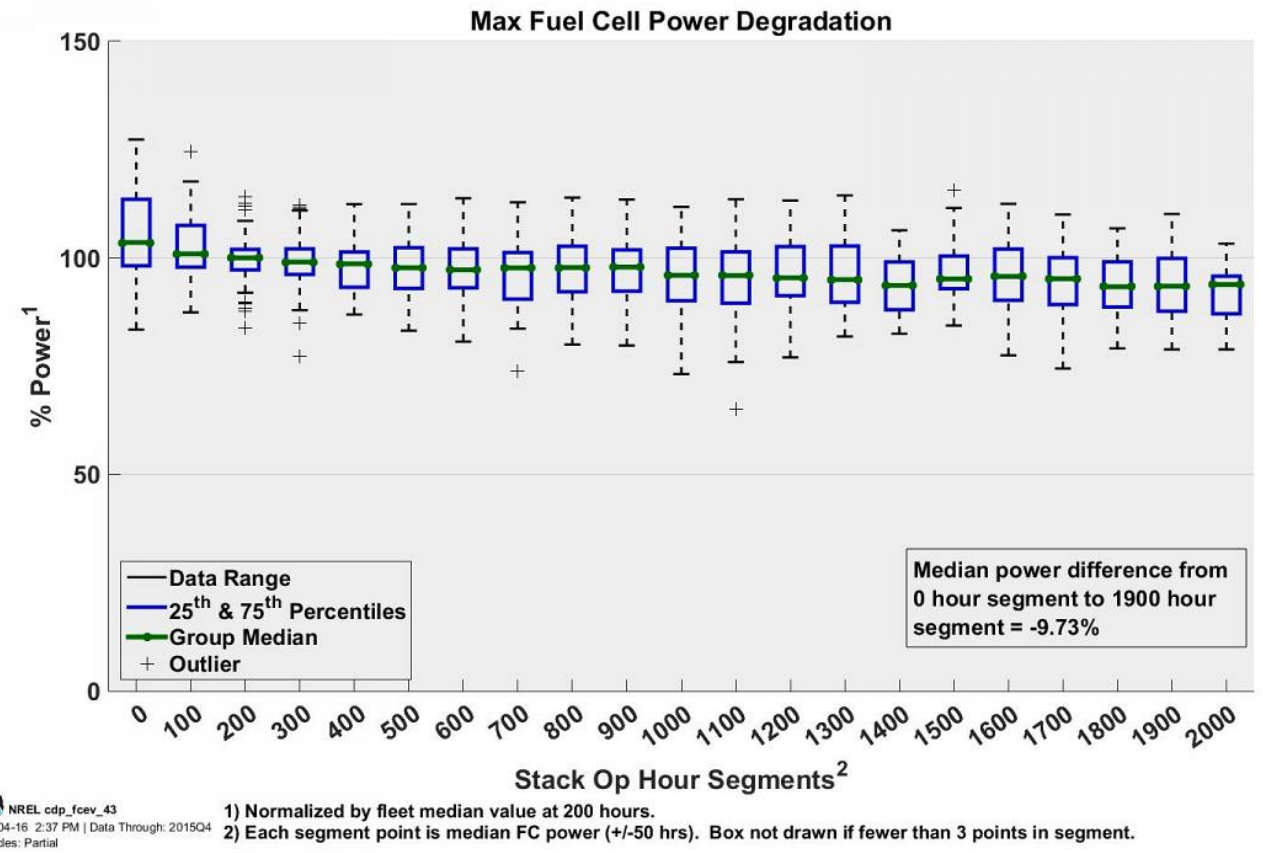

Figure 5. Max fuel cell power degradation over operation hour segments (CDP-FCEV-43) 


\section{Fuel Cell Performance}

In addition to providing data about on-road FCEV durability, vehicle manufacturers provided data specific to the fuel cell power plant, allowing NREL to examine fuel cell performance in terms of power output, voltage, efficiency, and stack energy. NREL evaluated the fuel cell system operation from several different perspectives to better understand whether the unique performance characteristics were being maximized. Figure 6 and Figure 7 compare fuel cell operating time to power and voltage respectively. Figure 6 reflects a typical urban driving cycle where FCEVs spend most of the time operating below 50\% peak power and a significant amount of time at or below 5\% peak power (at idle). Fleet data may not necessarily be reflective of typical consumer usage based on fleet operator determined drive cycle or regional factors (i.e., high traffic). In Figure 7 the percentages of time at rated maximum voltage complement the power levels observed in the previous figure (Figure 6) where the fleets are spending a large amount of time at low current and high voltage (at idle and urban driving).

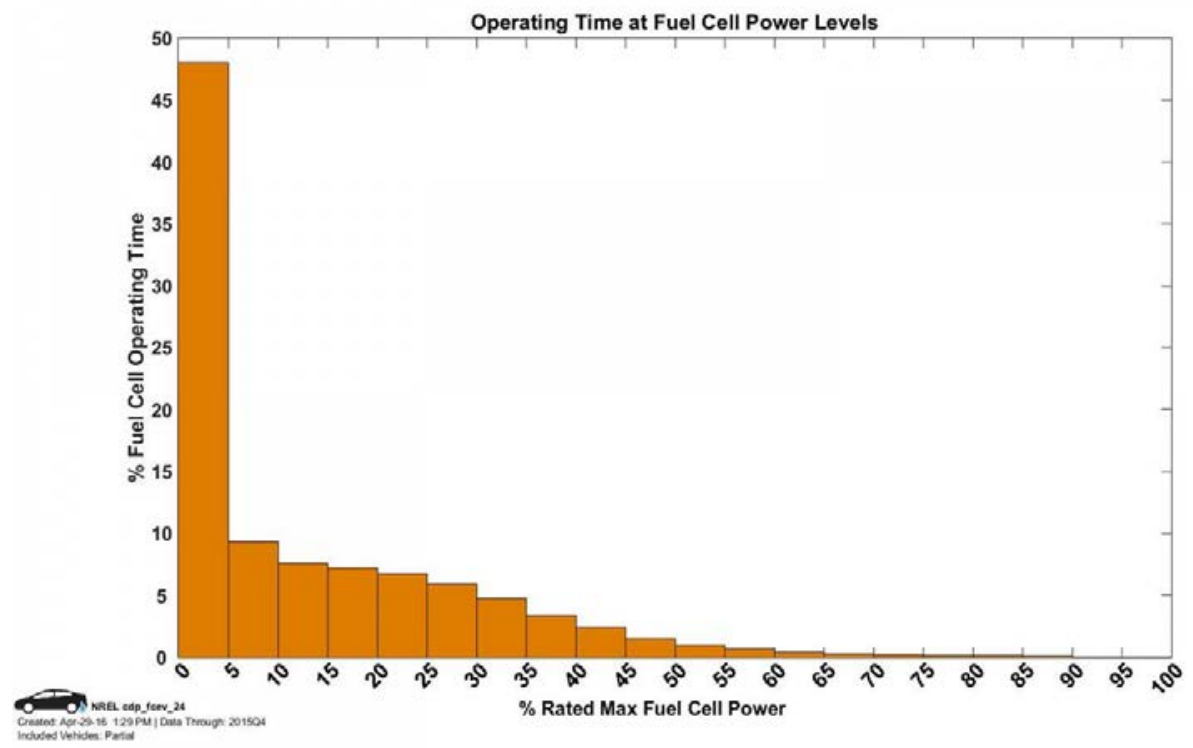

Figure 6. Operation time at fuel cell power levels (CDP-FCEV-24) 


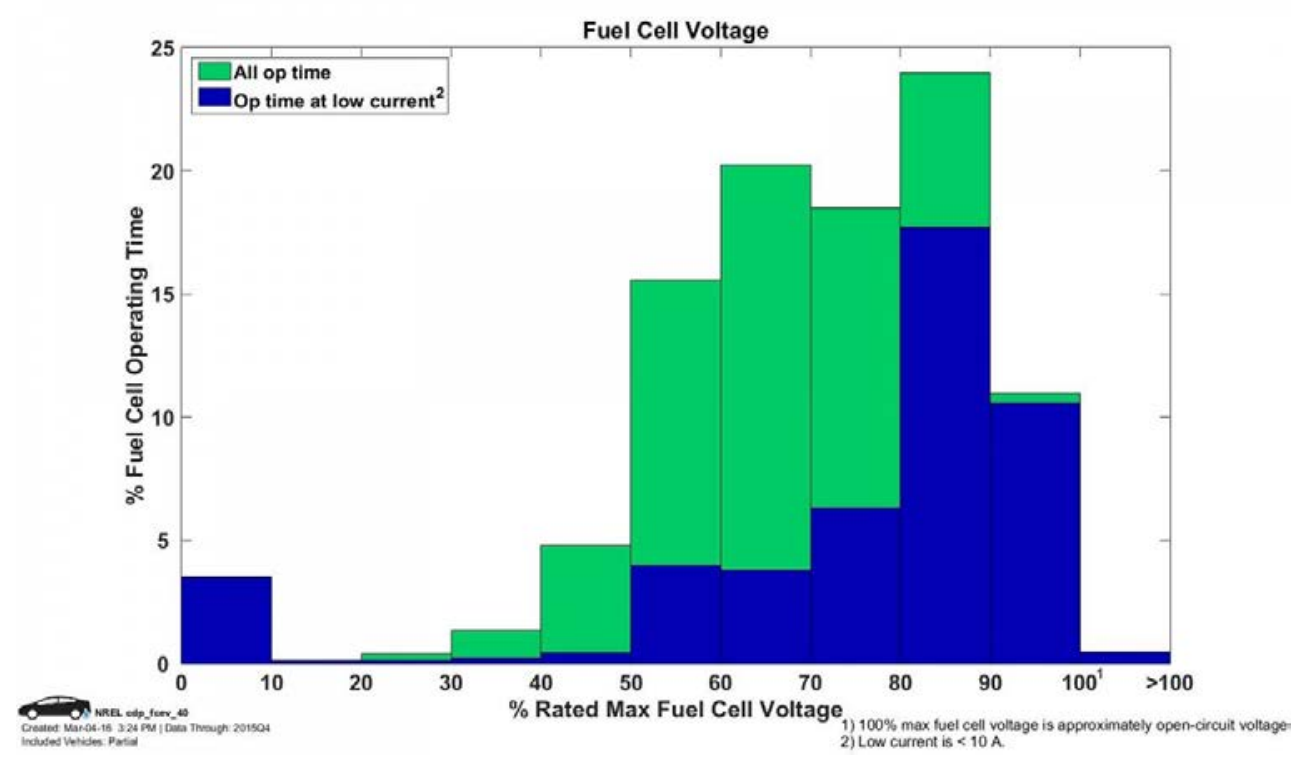

Figure 7. Operation time at fuel cell voltage levels (CDP-FCEV-40)

The DOE MYRD\&D 2020 target sets a goal of 65\% peak efficiency at 25\% rated power for direct hydrogen fuel cell power systems for transportation applications. Figure 8 provides a summary of fuel cell stack efficiency for both calculated and reported values. The calculated values are determined by the product of reported voltage and current readings divided by the fuel consumed, but they do not include parasitic losses of the balance-of-plant components or hydrogen purge losses. Fuel consumed is determined by the number of reported cells in a fuel cell stack and the Faraday constant. This results in higher calculated values than the reported system efficiency numbers recorded by the fleet operators. The reported system efficiency for the fleet at $25 \%$ rated power is approximately $57 \%$ and the calculated efficiency is approximately $60 \%$. The DOE 2020 target is denoted by a star on the figure. While good progress has been made and the calculated values are much closer to meeting the target, FCEV manufacturers will need to make improvements to achieve the efficiency target. 


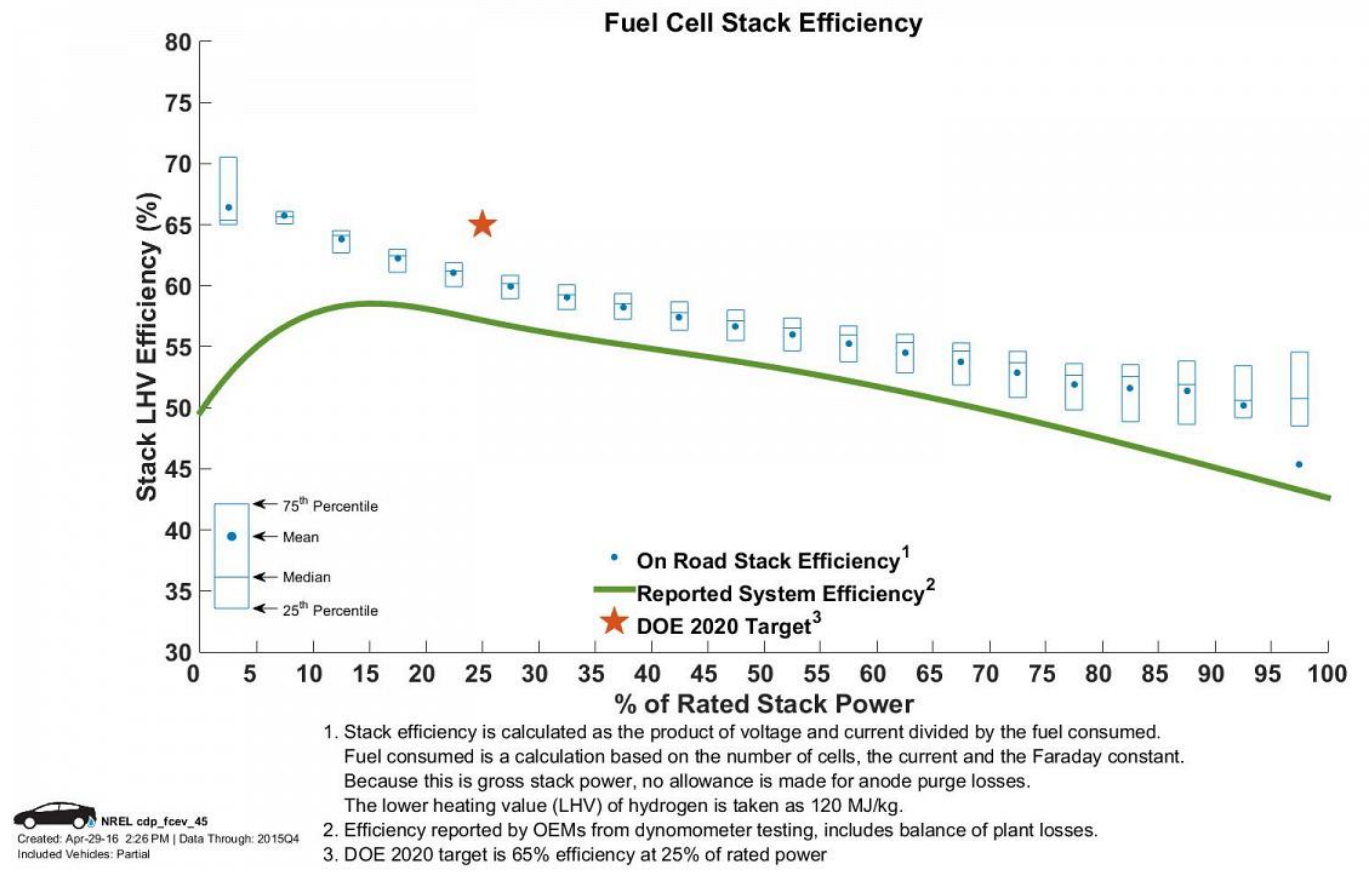

Figure 8. Voltage degradation projection by operation hours (CDP-FCEV-50)

Figure 9 provides a plot of fuel cell stack energy in relation to percentage of gross power output. The stack energy is reflective of an urban driving cycle (around town driving) with most of the stack output ranging from $20 \%$ to $35 \%$. Fuel cell stack energy also indicates that the peak efficiency (at approximately $25 \%$ rated power per DOE target) falls within the operating range observed during real word evaluation. Results from a companion analysis provide further evidence that the FCEVs are being operated in the same manner as internal combustion engine vehicles. See the Range section of the Fuel Cell Electric Vehicle Driving and Fueling Behavior report published in parallel with this analysis for additional information. 


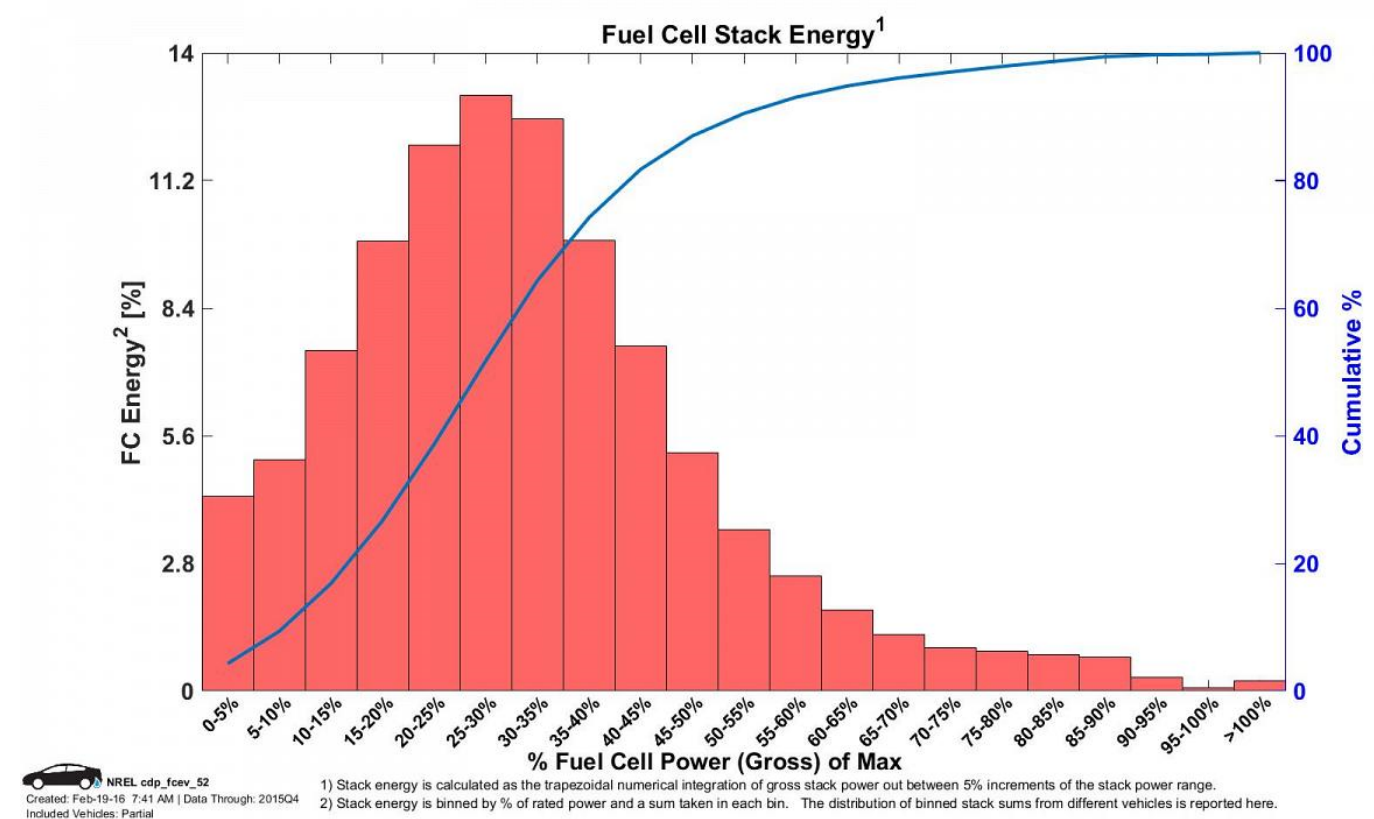

Figure 9. Voltage degradation projection by operation hours (CDP-FCEV-52) 


\section{Conclusion}

Through 12 years of real-world validation NREL has evaluated 230 deployed vehicles traveling 7.4 million miles of second-by-second data delivered and published more than $100 \mathrm{CDPs}$ to communicate the technical results to a broad audience of stakeholders. This project addressed the critical need for data analytics to inform both early-stage R\&D and commercial readiness of vehicle and station technologies. Detailed data products were sent to each contributing data partner and informed vehicle manufacturers how they compared to the overall industry performance, which supported internal R\&D decisions related to range, performance, and durability. Results have also been used to inform Technical Teams ${ }^{3}$ on progress against key technologies and identify gaps. A specific example is the fuel cell voltage degradation analysis, which provided a status against a technical target viewed as necessary for market competition. The degradation analysis also supported researchers through a comparison of single-cell voltage degradation with the fuel cell stack and balance of plant degradation. Researchers comparing test conditions and operation conditions allowed for statistical analysis of known degradation mechanisms like start/stops, transients, and time at open circuit voltage.

Significant improvements have been made in degradation and operation time of FCEV power plants since the first phase of the Learning Demonstration project, but the technology will need to improve in order to meet DOE MYRD\&D 2020 targets. To date, some fuel cell stacks in the fleet have exceeded the 5,000-hour operation time target, but degradation remains an issue. Fleets are on average experiencing $10 \%$ degradation between 2,000 to 3,000 hours of operation. The data indicates that, through the rate of improvement since the first Learning Demonstration phase, technology advancement should allow fuel cell stacks to meet the target in 2-4 years.

Fuel cell performance data show that the technology will need to continue to improve to meet DOE MYRD\&D 2020 targets of $65 \%$ peak efficiency at $25 \%$ rated power. FCEV fleets reported approximately $57 \%$ efficiency at $25 \%$ rated power. Voltage and power data indicate that the fuel cells are being operated at lower power levels under high voltage and low current scenarios. Power usage also mirrors range data showing that FCEVs are being driven in a manner similar to internal combustion engine cars.

FCEVs have advanced rapidly in recent years and as the automotive OEMs have released commercially available FCEV models. Performance and durability data generated during the technology validation project were crucial in validating DOE targets but also helped to update long-term targets and drive future research and development needs leading to more robust FCEVs.

NREL's website ${ }^{4}$ will continue to be the primary repository for NFCTEC's hydrogen fuel cell vehicle and infrastructure analysis results, as well as results from technology validation of other hydrogen components and systems.

\footnotetext{
${ }^{3}$ United States Council for Automotive Research LLC, https://uscar.org/guest/index.php

${ }^{4}$ https://www.nrel.gov/hydrogen/fuel-cell-vehicle-evaluation.html
} 


\section{References and Publications}

For the full list of published CDPs, please see NREL's website at https://www.nrel.gov/hydrogen/fuel-cell-electric-vehicle-cdps.html.

American Honda Motor Co., Inc. 2018. "Clarity Fuel Cell."

https://automobiles.honda.com/clarity-fuel-cell.

Borup, Rod, Jeremy Meyers, Bryan Pivovar, Yu Seung Kim, Nancy Garland, Deborah Myers, Rangachary Mukundan, Mahlon Wilson, Fernando Garzon, David Wood, Piotr Zelenay, Karren More, Tom Zawodzinski, James Boncella, James E. McGrath, Minoru Inaba, Kenji Miyatake, Michio Hori, Kenichiro Ota, Zempachi Ogumi, Seizo Miyata, Atsushi Nishikata, Zyun Siroma, Yoshiharu Uchimoto, and Kazuaki Yasuda. 2007. "Scientific Aspects of Polymer Electrolyte Fuel Cell Durability and Degradation.” Chem. Rev. 107 (10): 3904-3951.

Chen, Tan-Ping. 2008. "Hydrogen Delivery Infrastructure Options Analysis.” Friday Chevron Profile. Nexant, Inc.

FCTO (Fuel Cell Technologies Office). 2015. Fuel Cell Technologies Office Multi-Year Research, Development, and Demonstration Plan. Washington, DC: U.S. Department of Energy. https://www.energy.gov/eere/fuelcells/downloads/fuel-cell-technologies-office-multi-yearresearch-development-and-22.

Fueleconomy.gov. 2018. "Compare Fuel Cell Vehicles.” U.S. Department of Energy and U.S. Environmental Protection Agency. https://www.fueleconomy.gov/feg/fcv sbs.shtml.

Honda Worldwide. 2012. "FCX Clarity: Specifications." http://world.honda.com/FCXClarity/specifications/index.html.

Hydrogen Motors. 2006. “Chevrolet Equinox Fuel Cell (2006).” www.hydrogenmotors.com/chevrolet-equinox-fuel-cell.html.

Hyundai. 2018. "Hyundai Nexo: The Next-Generation Fuel Cell Vehicle." https://www.hyundaiusa.com/nexo/index.aspx.

Hyundai. 2011. "Hyundai Unveils Tucson ix Hydrogen Fuel Cell Electric Vehicle at Fuel Cell Hydrogen Energy 2011.” Press release. https:/www.hyundai.com/worldwide/en/abouthyundai/news-room/news/hyundai-unveils-tucson-ix-hydrogen-fuel-cell-electric-vehicle-at-fuelcell-hydrogen-energy-2011-0000001187.

Kurtz, Jennifer, Sam Sprik, Genevieve Saur, and Shaun Onorato. 2019. On-Road Fuel Cell Electric Vehicles Evaluation: Overview. Golden, CO: National Renewable Energy Laboratory.

Mercedes-Benz. 2017. “The New GLC F-CELL.” https://www.mercedesbenz.com/en/mercedes-benz/vehicles/passenger-cars/glc/the-new-glc-f-cell/.

Mercedes-Benz. 2012. "2012 Mercedes-Benz F-CELL Technical Data." https://media.mbusa.com/releases/2012-mercedes-benz-f-cell-technical-data. 
NHTS (National Household Travel Survey). 2009. “2009 NHTS Survey Data.” ASCII.csv. http://nhts.ornl.gov/download.shtml\#2009.

Nissan Motor Corporation. 2005. "New X-TRAIL Fuel Cell Vehicle (FCV)." https://www.nissan-global.com/EN/TECHNOLOGY/OVERVIEW/fcv.html.

Toyota. 2018. “2018 Toyota Mirai Fuel Cell Vehicle.” https://ssl.toyota.com/mirai/fcv.html.

Wipke, Keith, Donald Anton, and Sam Sprik. 2009. Evaluation of Range Estimates for Toyota FCHV-adv Under Open Road Driving Conditions. Savannah River National Laboratory. SRNSSTI-2009-00446. https://www.energy.gov/sites/prod/files/2014/03/f9/toyota_fchvadv_range_verification.pdf.

Wipke, Keith, Sam Sprik, Jennifer Kurtz, Todd Ramsden, Chris Ainscough, and Genevieve Saur. 2012. National Fuel Cell Vehicle Learning Demonstration Final Report. Golden, CO: National Renewable Energy Laboratory. NREL/TP-5600-54860. https://www.nrel.gov/docs/fy12osti/54860.pdf. 